\title{
PHYTOREMEDIATION POTENTIAL OF LEMONGRASS (CYMBOPOGON FLEXUOSUS STAPF.) GROWN ON TANNERY SLUDGE CONTAMINATED SOIL
}

\author{
KHILJI, S. A. ${ }^{1}-$ SAJID, Z. A. ${ }^{2 *}$ \\ ${ }^{1}$ Department of Botany, Division of Science and Technology, University of Education, Lahore \\ 54770, Punjab, Pakistan \\ ${ }^{2}$ Department of Botany, University of the Punjab, Lahore 54590, Punjab, Pakistan \\ *Corresponding author \\ e-mail: zahoor.botany@pu.edu.pk; phone: +92-334-740-7566
}

(Received $7^{\text {th }}$ Jun 2020; accepted $17^{\text {th }}$ Sep 2020)

\begin{abstract}
Phytoremediation is one of the safest and sustainable approaches to reclaim metal contaminated soil. The present study assessed the phytoremediation potential of lemongrass (Cymbopogon flexuosus Stapf.) by growing it on soil mixed with different concentrations of tannery sludge i.e., 5, 10 and 15\% regarded as 5\% TS + S, 10\% TS + S, and 15\% TS + S whereas the soil without tannery sludge was taken as control $(0 \% \mathrm{TS}+\mathrm{S})$. After 35 days of growth, the plants were harvested to record various morpho-physiological attributes and accumulation of various heavy metals in above and below ground plant parts. Results revealed that soil mixed with TS reduced the morphological attributes i.e., the fresh weight, dry weight, number of roots, number of leaves, number of tillers, and shoot length up to $37.50,26.86,23.46,56.25,16.13$ and $19.31 \%$. Moreover, tannery sludge application enhanced the free radicals i.e., 2, 2-diphenyl-1-picrylhydrazyl (DPPH) and regulated the antioxidant activities. Overall metal uptake was higher in the root than shoot whereas the amount of heavy metals uptake by plants was the highest at $15 \%$ concentration. The trend of metal uptake was recorded as: $\mathrm{Cr}>\mathrm{Cd}>\mathrm{Cu}>\mathrm{Mg}>\mathrm{Fe}>\mathrm{Zn}>\mathrm{Ni}>\mathrm{Pb}$.
\end{abstract}

Keywords: antioxidants, chlorophyll contents, diphenyl picrylhydrazyl, lemongrass, metals

\section{Introduction}

Environmental pollution is a major challenge of current century and poses serious threats to environment, agro-ecosystems and food safety (Ali and Khan, 2017; Hashem et al., 2017). Heavy metals are comparatively more dangerous than other pollutants because of its long persistence and ubiquitous nature (Lou et al., 2015; Ashraf et al., 2015). If level of these heavy metals exceeded by given threshold limits, it will impose devastating effects on living beings and their biological functions (Peng et al., 2009). Categorically, pollution is divided in to several types e.g., air, water, noise and soil pollution (Azizullah et al., 2011; Henschel et al., 2012). Consequently, soil pollution has only recently attracted considerable attention (Ashraf et al., 2017). Soil quality is directly related to food safety, human health, and sustainable economic and social development (Teng et al., 2014; Ashraf et al., 2018). Soil contamination with various heavy metals is one of the main threats for agricultural production systems (Ashraf and Tang, 2017; Beesley et al., 2011; Ali et al., 2013).

Leather industry is largely responsible for environmental pollution, due to the use of various hazardous chemicals in leather processing. For example, the skin of sheep, buffaloes, cows and camels are treated by these industries and almost 130 types of different potent chemicals are used for every different kind of material to be processed (Bareen and Tahira, 2011). Upon entrance, heavy metals interfere with plant 
metabolism and thus caused morpho-physiological and biochemical changes in plants (Morkunas et al., 2018). In general, over production of reactive oxygen species (ROS), superoxide free radicals, hydroxyl free and non-free radical species such as oxygen and hydrogen peroxide are associated with highest metal uptake. Production of some cytotoxic compounds like methylglyoxal also disturbs the balance between pro-oxidant and anti-oxidant homeostasis within the plant cells thus causing oxidative stress (Oliveira et al., 2012; Thanikaivelan et al., 2005). Overall, heavy metal contamination reduced growth and productivity of crop plants by altering morpho-physiological functions and crop growth. Therefore, developments of various methodologies/ techniques are required to remediate the heavy metal contaminated soils. Bioremediation is also an eco-friendly approach to cleanse the metal polluted soils where hyperaccumulator plants are grown on contaminated lands either alone or with combination of suitable microbes (Edward, 2013).

Lemongrass (Cymopogon flexuosus L.) is an economically important herb and widely cultivated over the globe. It is used for versatile purposes e.g., leaves are used as green tea, stem in soups, poultry items and seafood (Jasha and Chase, 2014). Its leaves and inflorescence also produce an essential oil that is used in aromatherapy, perfumes and medicines (Verma et al., 2014). Lemongrass also exhibits various anti-cancerous (Kumar et al., 2008), antioxidant (Anand et al., 2011), antimicrobial, insecticidal (Rajeswara et al., 2015) and anti-inflammatory (Figueirinha et al., 2010) properties. Polyphenols, is a natural antioxidant, extracted from lemongrass, has been reported from preventing many diseases like cancers, cardiovascular, and degenerative diseases (Ogura et al., 2008). Hence, medicinal properties of Lemongrass are well recognized and widely acknowledged world-wide; however, its phyto-remediation potential in heavy metal contaminated soil was rarely investigated and/or explored. The present study was therefore conducted to evaluate the uptake and accumulation behavior of different heavy metals and/or phytoremediation potential of Lemongrass in tannery sludge contaminated soil.

\section{Materials and methods}

\section{Experimental details}

The samples were collected from sludge dumping site of Kasur Tannery Waste Management Agency (KTWMA) Kasur, Pakistan ( $31^{\circ} 05^{\prime} 16.32^{\prime}$ N, $74^{\circ} 28$ ' 36.20” E; Fig. 1). Samples of tannery sludge were collected and stored in plastic drums. The garden soil samples were collected in polythene bags from the lawns of University of Education, Lahore. The respective samples of soil were sieved through a sieve mesh size of $2 \mathrm{~cm}^{2}$ for further use. The experiment was set-up in the wire-house of Department of Botany, University of Education, Township Lahore, Pakistan. The treatments were comprised of four different concentrations of tannery sludge mixed with soil i.e., $0 \%$ Soil (Garden soil as a control), 5\% TS + S (5 g of tannery sludge in $95 \mathrm{~g}$ of soil), $10 \% \mathrm{TS}+\mathrm{S}$ (10 g of tannery sludge in $90 \mathrm{~g}$ of soil) and $15 \% \mathrm{TS}+\mathrm{S}$ (15 g of tannery sludge in $85 \mathrm{~g}$ of soil) with three replicate. The experiment was setup in the month of November, 2018. The fresh seedlings $(15 \mathrm{~cm})$ of lemongrass were transplanted (one plant/pot) and were irrigated regularly with tap water (Fig. 2). After 35 days of growth, the plants were harvested to record the fresh and dry weight, number of roots, leaves and tiller per plant, and shoot length whilst the leaf chlorophyll contents were measured by SPAD meter (SPAD-502 Plus, Japan). 


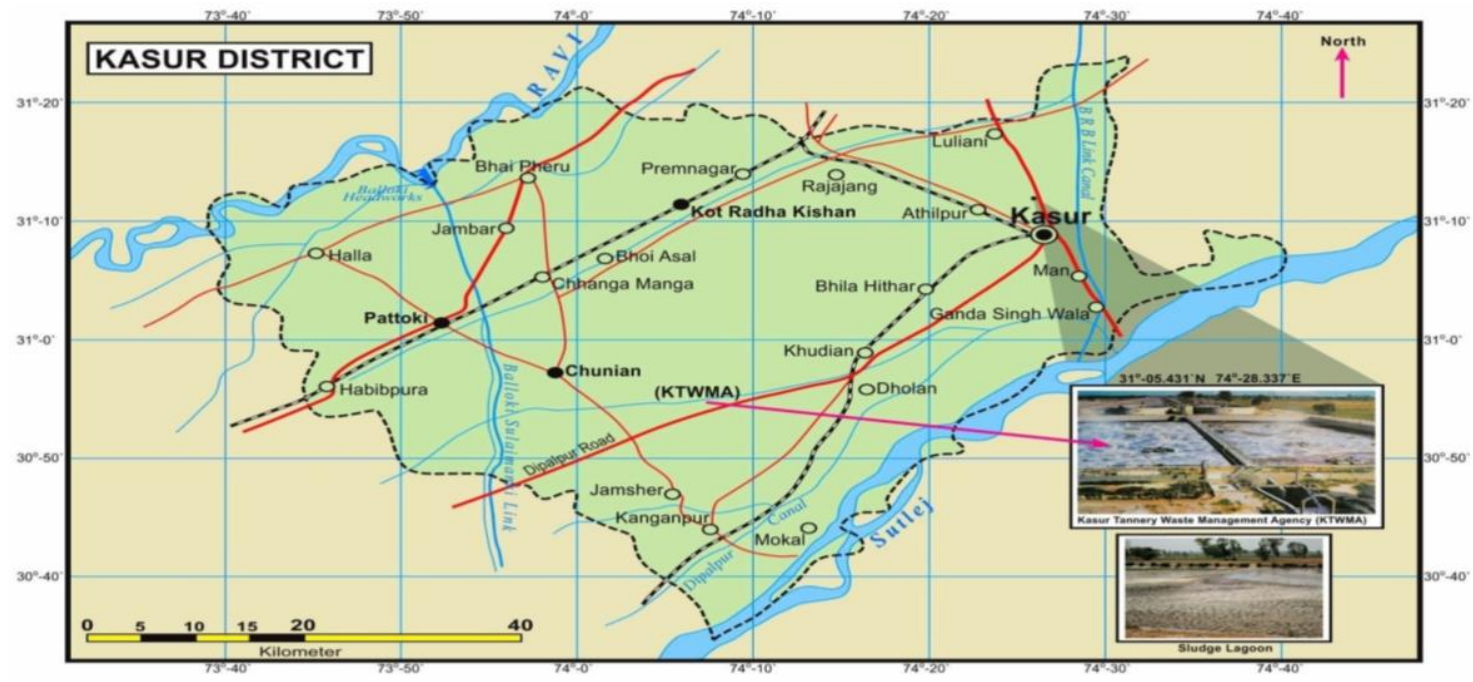

Figure 1. The map of the Kasur District showing location of the sampling site

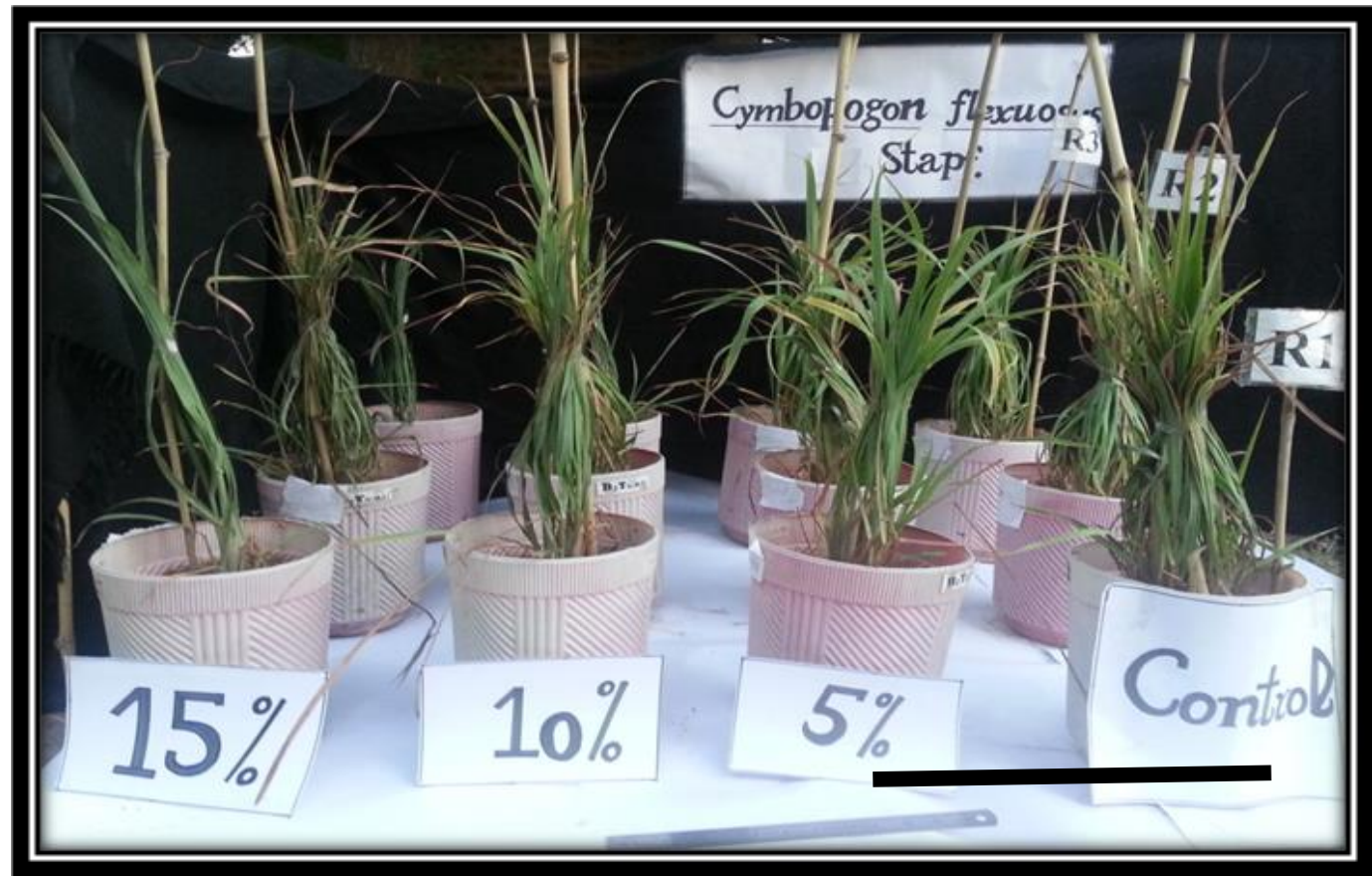

Figure 2. Plants of lemongrass growing on different concentrations of tannery sludge amended soil i.e. 0, 5, 10, and $15 \%$ after 35 days of exposure. Scale bar $=20 \mathrm{~cm}$

\section{Pre-sowing physico-chemical analysis of soil amended with different concentrations of sludge}

The $\mathrm{pH}$ and electrical conductivity (EC) of soil and sludge were determined by using Multiparameter (Model HI 9835, HANNA), carbonates and biocarbonates, chlorides were determined in different concentrations of soil and sludge by titration methods (Saeed, 1980). The organic matter content was estimated by using Muffle Furnace (Ney Vulcan, D-550, Dentsply Ceramco, USA; Ball, 1964). The bulk density of sludge was estimated by the given formula (Eq. 1): 


$$
\text { Bulk density }\left[\left(\mathrm{cm}^{3}\right)^{-1}\right]=\frac{\text { Mass of the dried sludge }(\mathrm{g})}{\text { Volume of the container }}
$$

\section{Acid digestion of plants, sludge and soil samples for the estimation of heavy metals}

The soil and sludge samples were digested by using $\mathrm{HNO}_{3}$ and $\mathrm{HClO}_{4}(1: 4)$ and then $4 \mathrm{ml}$ of $\mathrm{HNO}_{3}: \mathrm{H}_{2} \mathrm{O}(1: 1)$ were added and heated on hot plate at $85{ }^{\circ} \mathrm{C}$ for $30 \mathrm{~min}$ to reduce the volume to half (Greenberg et al., 1998). The digested samples were then filtered and final volume was made up to $100 \mathrm{ml}$ with distilled water. The solution was then filtered and used for the estimation of metals by using Atomic Absorption Spectrophotometer (GBC Savant AA, Australia).

\section{Antioxidant analysis based on the scavenging of 2, 2-diphenyl-1-picrylhydrazyl (DPPH) radical}

Preparation $0.002 \%$ ascorbic acid solution for standard curve

Ascorbic acid ( $2 \mathrm{mg}$ ) was dissolved in $25 \mathrm{ml}$ of distilled water with constant stirring for 5-10 min. Then the final volume of solution was raised up to $1000 \mathrm{ml}$ by adding distilled water. The prepared solution was saved in a dark bottle in the refrigerator (Brand Williams et al., 1995).

\section{Standard curve of ascorbic acid}

For sample preparation, $3.9 \mathrm{ml}$ of DPPH (2, 2-diphenyl-1-picrylhydrazyl) with $0.1 \mathrm{ml}(100 \mu \mathrm{M})$ of solution prepared from every dilution $\left(2-20 \mu \mathrm{g} \mathrm{ml}^{-1}\right)$ of ascorbic acid, was taken in different test tubes. Prepared sample of DPPH was taken as control as well as blank. Initial readings of all the samples were taken on Spectrophotometer (T80 + UV/VIS Spectrophotometer, PG, UK) at $517 \mathrm{~nm}$, which was then kept in dark for 30 min to let the reaction take place. Then final reading was taken to determine the leftover DPPH. Scavenging activity of DPPH was expressed as optical density (OD).

\section{Preparation of plant leaves extract}

Fresh leaves samples (15 g) were taken from plants growing on different concentrations $(0-15 \%)$ of Tannery sludge amended soil and air-dried in dark at the room temperature. Then the plant sample was grinded to fine powder for the sake of extract preparation. The powdered leaves were soaked in $100 \mathrm{ml}$ of $100 \%$ methanol and kept on orbital shaker for $24 \mathrm{~h}$. After that the sample was filtered with Whatman filter paper no. 1 and it was evaporated by rotary evaporator to obtain the final plant extract which was then diluted for further experiment.

\section{DPPH assay}

The capability of Cymbopogon to scavenging DPPH free radical was determined by using DPPH assay (Clark et al., 2013). DPPH $\left\{\left(0.0024 \mathrm{~g}\left(6 \times 10^{-5} \mathrm{M}\right)\right\}\right.$ was dissolved into $100 \mathrm{ml}$ of $100 \%$ methanol for the preparation of stock solution of DPPH. Scavenging activity of \% of extract was measured by using following formula (Eq. 2):

$$
\% \text { Radical Scavenged }=\frac{\text { Absorbance of control-Absorbance of sample }}{\text { Absorbance of control }}
$$




\section{Statistical analysis}

The least significance difference of calculated means for selected parameters for the data was statistically analyzed by using SPSS software 20.0.0. The differences amongst means were compared according to least significant difference (LSD) test at $5 \%$ probability level. Duncan's multiple range tests were also done to compare means.

\section{Results}

Pre-sowing of plant and post-harvest analysis of soil amended with different concentrations of tannery sludge

All physico-chemical properties of soil varied with the different concentrations of sludge application. For instance, carbonates were absent in all concentrations of sludge whereas, bicarbonates were $21,45,49,56 \mathrm{mg} \mathrm{L}^{-1}$, in $0,5,10$ and $15 \%$ concentrations of tannery sludge, respectively. Moreover, $15 \%(\mathrm{TS}+\mathrm{S})$ has the highest $\mathrm{pH}, \mathrm{EC}$, bicarbonates, chlorides, bulk density and organic matter \% than rest of the concentrations of tannery sludge amended soil. The amount of heavy metals was enhanced with increasing concentration of tannery sludge. The order of heavy metals at various concentrations of tannery sludge were remained as $\mathrm{Cr}>\mathrm{Cd}>\mathrm{Cu}>\mathrm{Zn}>\mathrm{Mg}>\mathrm{Ni}>\mathrm{Fe}>\mathrm{Pb}$.

The TS application altered the physico-chemical characteristics of soil after 35 days of experiment. The $\mathrm{pH}$ values were reduced i.e., at 5\% TS (8.11-8.01), $10 \%$ TS (8.20-8.12) and 15\%TS (8.70-8.37), respectively. Similarly, chloride content was reduced from 28.45 to $18.5 \mathrm{mg} \mathrm{L}^{-1}$ and bicarbonates from 56 to $49 \mathrm{mg} \mathrm{L}^{-1}$ was calculated in $15 \%$ TS. Heavy metal content was also reduced after 35 days of harvesting. The percentage reduction was found to be maximum for $\mathrm{Cr}$ as compared to all other TS concentrations. Similarly, all other metals reduced gradually in all concentrations of tannery sludge amended soil. The percentage reduction for highest concentration of tannery sludge i.e., $15 \%$ TS was found to be for $\mathrm{Cd}(23 \%), \mathrm{Cr}$ (35\%), $\mathrm{Cu}(16 \%), \mathrm{Fe}(36 \%), \mathrm{Mg}(49 \%), \mathrm{Ni} 32 \%), \mathrm{Pb}(31 \%)$ and $\mathrm{Zn}(49 \%)$ as compared to the control respectively (Table 1 ).

\section{Morphological attributes and chlorophyll contents}

The tannery sludge substantially reduced the morphological characters and chlorophyll contents in lemongrass. After 35 days of plants growth, the fresh/dry weight was: $128.33,34.67 \mathrm{~g}$ and chlorophyll contents were 52.76 in control plants while the no. of leaves, roots and tillers was 75, 93, and 36, respectively. The shoot length was also higher $(74.33 \mathrm{~cm})$ as compared to the various TS concentrations. All the above-mentioned parameters were reduced significantly in plants growing at 5 , 10 and $15 \%$ concentration of tannery sludge in soil. The fresh/dry weight and chlorophyll content was 93.33 and $27.33 \mathrm{~g} 37.70$ respectively at $15 \%$ concentration of sludge. Similarly, the no. of leaves/roots/tillers was 48, 75, and 31, respectively. Dose-dependent reduction in seedling length was also observed up to $62.3 \mathrm{~cm}$ at $15 \%$ concentration of sludge. Moreover, the chlorophyll contents were also decreased by $8.11,25.92$, and $39.95 \%$ at 5,10 and $15 \%(\mathrm{TS}+\mathrm{S})$ as compared with control. The growth variation of lemongrass before and after 35 -days of experiment is presented in Table 2. 
Table 1. Pre-sowing and post-harvest physico-chemical analysis of soil amended with different concentrations tannery sludge

\begin{tabular}{|c|c|c|c|c|c|c|c|c|}
\hline \multirow{2}{*}{ Parameters } & $\begin{array}{c}\text { Pre-sowing } \\
\text { analysis }\end{array}$ & $\begin{array}{c}\text { Post-harvest } \\
\text { analysis }\end{array}$ & $\begin{array}{c}\text { Pre-sowing } \\
\text { analysis }\end{array}$ & $\begin{array}{c}\text { Post-harvest } \\
\text { analysis }\end{array}$ & Pre-sowing analysis & $\begin{array}{c}\text { Post-harvest } \\
\text { analysis }\end{array}$ & $\begin{array}{c}\text { Pre-sowing } \\
\text { analysis }\end{array}$ & $\begin{array}{l}\text { Post-harvest } \\
\text { analysis }\end{array}$ \\
\hline & \multicolumn{2}{|c|}{$\begin{array}{c}\text { 0\% } \\
\text { (Soil only) }\end{array}$} & \multicolumn{2}{|c|}{$\begin{array}{c}\mathbf{5 \%} \\
(\mathbf{T S}+\mathbf{S})\end{array}$} & \multicolumn{2}{|c|}{$\begin{array}{c}10 \% \\
(\mathrm{TS}+\mathrm{S})\end{array}$} & \multicolumn{2}{|c|}{$\begin{array}{c}15 \% \\
(\mathrm{TS}+\mathrm{S})\end{array}$} \\
\hline $\mathrm{pH}$ & $8.01 \pm 0.01^{\mathrm{c}}$ & $7.90 \pm 0.005^{\text {cd }}$ & $8.11 \pm 0.1^{\mathrm{bc}}$ & $8.01 \pm 0.008^{c}$ & $8.20 \pm 0.01^{\mathrm{bc}}$ & $8.12 \pm 0.002^{\mathrm{bc}}$ & $8.70 \pm 0.02^{\mathrm{a}}$ & $8.37 \pm 0.007^{\mathrm{b}}$ \\
\hline $\operatorname{ECe}\left(\mathrm{dS} \mathrm{cm}^{-1}\right)$ & $1.30 \pm 0.09^{\mathrm{cd}}$ & $1.10 \pm 0.001^{\mathrm{d}}$ & $1.50 \pm 0.08^{\mathrm{c}}$ & $1.22 \pm 0.006^{\mathrm{cd}}$ & $2.92 \pm 0.01^{\mathrm{b}}$ & $2.22 \pm 0.001^{\mathrm{bc}}$ & $3.74 \pm 0.01^{\mathrm{a}}$ & $2.89 \pm 0.001^{\mathrm{b}}$ \\
\hline Bicarbonates $\left(\mathrm{mg} \mathrm{L}^{-1}\right)$ & $21.00 \pm 0.05^{\mathrm{cd}}$ & $14.00 \pm 0.04^{\mathrm{d}}$ & $45.00 \pm 0.08^{\mathrm{ab}}$ & $31.00 \pm 0.01^{\mathrm{c}}$ & $49.00 \pm 0.01^{\mathrm{ab}}$ & $37.00 \pm 0.08^{\mathrm{c}}$ & $56.00 \pm 0.04^{\mathrm{a}}$ & $49.00 \pm 0.12^{\mathrm{ab}}$ \\
\hline Carbonates $\left(\mathrm{mg} \mathrm{L}^{-1}\right)$ & ND & ND & ND & ND & ND & ND & ND & ND \\
\hline Chlorides $\left(\mathrm{mg} \mathrm{L}^{-1}\right)$ & $3.50 \pm 0.03^{\mathrm{d}}$ & $2.60 \pm 0.06^{\mathrm{e}}$ & $7.1 \pm 0.01^{\mathrm{c}}$ & $6.50 \pm 0.02^{\mathrm{cd}}$ & $17.75 \pm 0.01^{\mathrm{b}}$ & $13.80 \pm 0.07^{\mathrm{bc}}$ & $24.85 \pm 0.00^{\mathrm{a}}$ & $18.50 \pm 0.04^{b}$ \\
\hline Bulk density $\left[\mathrm{g}\left(\mathrm{cm}^{3}\right)^{-1}\right]$ & $1.21 \pm 0.01^{\mathrm{a}}$ & $0.77 \pm 0.10^{\mathrm{d}}$ & $1.15 \pm 0.06^{\mathrm{ab}}$ & $0.33 \pm 0.01^{\mathrm{de}}$ & $1.09 \pm 0.02^{\mathrm{bc}}$ & $0.10 \pm 0.05$ & $1.02 \pm 0.01^{\mathrm{c}}$ & $0.03 \pm 0.08^{\mathrm{e}}$ \\
\hline Organic matter content $(\%)$ & $5.60+0.10^{c}$ & $3.22 \pm 0.11^{\mathrm{d}}$ & $12.00 \pm 0.06^{\mathrm{ab}}$ & $8.00 \pm 0.04^{\mathrm{b}}$ & $16.00 \pm 1.2^{\mathrm{ab}}$ & $11.56 \pm 0.06^{\mathrm{ab}}$ & $19.00 \pm 0.80^{\mathrm{a}}$ & $5.33 \pm 0.01^{\mathrm{c}}$ \\
\hline $\mathrm{Cd}\left(\mathrm{mg} \mathrm{kg}^{-1}\right)$ & ND & ND & $3199 \pm 1.34^{\mathrm{d}}$ & $2518 \pm 1.27^{\mathrm{e}}$ & $5557 \pm 1.29^{\mathrm{b}}$ & $4635 \pm 098^{c}$ & $6588 \pm 166^{\mathrm{a}}$ & $5011 \pm 0.99^{\mathrm{bc}}$ \\
\hline $\mathrm{Cr}\left(\mathrm{mg} \mathrm{kg}^{-1}\right)$ & ND & ND & $4268 \pm 1.28^{\mathrm{d}}$ & $2420 \pm 1.21^{\mathrm{e}}$ & $6135 \pm 1.40^{\mathrm{b}}$ & $4701 \pm 1.66^{\mathrm{d}}$ & $8627 \pm 1.27^{\mathrm{a}}$ & $5582 \pm 1.43^{\mathrm{c}}$ \\
\hline $\mathrm{Cu}\left(\mathrm{mg} \mathrm{kg}^{-1}\right)$ & ND & ND & $2298 \pm 1.34^{\mathrm{d}}$ & $1892 \pm 1.58^{\mathrm{e}}$ & $3798 \pm 1.65^{\mathrm{c}}$ & $3168 \pm 1.55^{\mathrm{cd}}$ & $6340 \pm 1.32^{\mathrm{a}}$ & $5298 \pm 1.29^{\mathrm{b}}$ \\
\hline $\mathrm{Fe}\left(\mathrm{mg} \mathrm{kg}^{-1}\right)$ & ND & ND & $1223 \pm 1.30^{\mathrm{d}}$ & $996 \pm 1.67^{\mathrm{e}}$ & $1527 \pm 1.68^{b}$ & $1161 \pm 1.20^{\mathrm{de}}$ & $1967 \pm 1.23^{\mathrm{a}}$ & $1345 \pm 1.16^{\mathrm{c}}$ \\
\hline $\operatorname{Mg}\left(\mathrm{mg} \mathrm{kg}^{-1}\right)$ & ND & ND & $1359 \pm 1.70^{c}$ & $1019 \pm 1.19^{\mathrm{cd}}$ & $2243 \pm 1.2^{\mathrm{b}}$ & $1561 \pm 1.01^{\mathrm{c}}$ & $4002 \pm 1.19^{\mathrm{a}}$ & $2027 \pm 1.23^{\mathrm{b}}$ \\
\hline $\mathrm{Ni}\left(\mathrm{mg} \mathrm{kg}^{-1}\right)$ & ND & ND & $1700 \pm 1.10^{\mathrm{d}}$ & $1558 \pm 1.41^{\mathrm{de}}$ & $2563 \pm 1.58^{\mathrm{c}}$ & $2219 \pm 1.29^{\mathrm{cd}}$ & $3339 \pm 1.20^{\mathrm{a}}$ & $3046 \pm 1.55^{\mathrm{ab}}$ \\
\hline $\mathrm{Pb}\left(\mathrm{mg} \mathrm{kg}^{-1}\right)$ & ND & ND & $344 \pm 1.21^{\mathrm{c}}$ & $240 \pm 1.07^{\mathrm{d}}$ & $426 \pm 1.45^{\mathrm{bc}}$ & $204 \pm 1.67^{\mathrm{d}}$ & $821 \pm 1.21^{\mathrm{a}}$ & $561 \pm 1.50^{\mathrm{b}}$ \\
\hline $\mathrm{Zn}\left(\mathrm{mg} \mathrm{kg}^{-1}\right)$ & ND & ND & $2230 \pm 1.31^{\mathrm{c}}$ & $1053 \pm 1.29^{\mathrm{e}}$ & $3060 \pm 1.35^{\mathrm{b}}$ & $1801 \pm 1.70^{\mathrm{d}}$ & $4408 \pm 1.21^{\mathrm{a}}$ & $2231 \pm 1.44^{\mathrm{c}}$ \\
\hline
\end{tabular}

Values are means \pm SE of 9 replicates. Means values followed by a same letter in the rows are not significantly different at $\mathrm{P}<0.05$ by Duncan's multiple range test. ND $=$ not detected; TS $=$ tannery sludge

Table 2. Morphological attributes and chlorophyll contents of lemongrass grown in different concentrations of tannery sludge (TS) amended soil

\begin{tabular}{|c|c|c|c|c|c|}
\hline \multirow[b]{2}{*}{ Parameters } & \multicolumn{5}{|c|}{ Treatments } \\
\hline & $\begin{array}{c}0 \% \\
\text { (Soil only) }\end{array}$ & $\begin{array}{c}\mathbf{5 \%} \\
(\mathrm{TS}+\mathrm{S})\end{array}$ & $\begin{array}{c}10 \% \\
(\mathrm{TS}+\mathrm{S})\end{array}$ & $\begin{array}{c}15 \% \\
(\mathrm{TS}+\mathrm{S})\end{array}$ & $\begin{array}{c}\text { LSD } \\
(\mathbf{P}<0.05) \\
\end{array}$ \\
\hline Fresh weight (g) & $128.33 \pm 6.18^{a}$ & $121.63 \pm 5.3^{\mathrm{b}}$ & $107.67^{ \pm} 7.4^{\mathrm{c}}$ & $93.33 \pm 9.28^{\mathrm{d}}$ & 12.02 \\
\hline Dry weight (g) & $34.67 \pm 2.86^{\mathrm{a}}$ & $33.00 \pm 1.63^{\mathrm{b}}$ & $30.33^{ \pm} 3.85^{\mathrm{c}}$ & $27.33 \pm 5.79^{d}$ & 7.56 \\
\hline Number of roots & $93.00^{ \pm} 2.44^{\mathrm{a}}$ & $86.67 \pm 4.49^{b}$ & $80.00 \pm 1.63^{\mathrm{c}}$ & $75.33 \pm 3.29^{d}$ & 9.33 \\
\hline Number of leaves & $75.00 \pm 3.29^{\mathrm{a}}$ & $73.00 \pm 8.17^{\mathrm{b}}$ & $60.00 \pm 6.23^{c}$ & $48.00 \pm 2.49^{\mathrm{d}}$ & 11.20 \\
\hline Number of tillers & $36.00 \pm 1.69^{\mathrm{a}}$ & $34.00 \pm 2.86^{\mathrm{b}}$ & $32.00^{ \pm} 5.79^{c}$ & $31.00 \pm 4.49^{\mathrm{bc}}$ & 5.6 \\
\hline Shoot length $(\mathrm{cm})$ & $74.33 \pm 3.29^{\mathrm{a}}$ & $72.67 \pm 5.79^{b}$ & $66.67 \pm 1.69^{\mathrm{c}}$ & $62.30 \pm 2.49^{\mathrm{d}}$ & 8.56 \\
\hline Chlorophyll contents & $52.76 \pm 1.47^{\mathrm{a}}$ & $48.80 \pm 1.97^{\mathrm{b}}$ & $41.90 \pm 1.22^{\mathrm{c}}$ & $37.70 \pm 3.12^{\mathrm{d}}$ & 13.28 \\
\hline
\end{tabular}

Values are the means \pm standard deviation of 9 replicates. Means values followed by a same letter in the rows are not significantly different at $\mathrm{P}<0.05$ by Duncan's multiple range test. LSD: least significant difference at $\mathrm{P}<0.05$

APPLIED ECOLOGY AND ENVIRONMENTAL RESEARCH 18(6):7703-7715.

http://www.aloki.hu • ISSN 15891623 (Print) • ISSN 17850037 (Online)

DOI: http://dx.doi.org/10.15666/aeer/1806_77037715

(c) 2020, ALÖKI Kft., Budapest, Hungary 


\section{Heavy metal accumulation in root and shoot}

The concentration of heavy metals in root and shoot plants was increased in a dose dependent manner of TS and remained the highest at 15\% TS $+\mathrm{S}$ as compared to other TS treatments. The overall trend of metal uptake at 15\% TS was recorded in order of: $\mathrm{Cr}>\mathrm{Cd}>\mathrm{Cu}>\mathrm{Mg}>\mathrm{Fe}>\mathrm{Zn}>\mathrm{Ni}>\mathrm{Pb}$ both in root and shoot. At 15\% TS treatments, the contents of $\mathrm{Cd}, \mathrm{Cr}, \mathrm{Cu}, \mathrm{Fe}, \mathrm{Ni}, \mathrm{Mg}, \mathrm{Pb}, \mathrm{Zn}$ were increased up to 87.68, 91.21, 92.54, $64.16,61.19,87.65,57.43$, and $43.69 \%$ in root and 79.58, 83.01, 64.23, 71.43, 74.06, $81.33,41.73$, and $68.05 \%$ in shoot as compared with control. Comparatively, the metal contents were found higher in roots than shoots (Fig. 3).

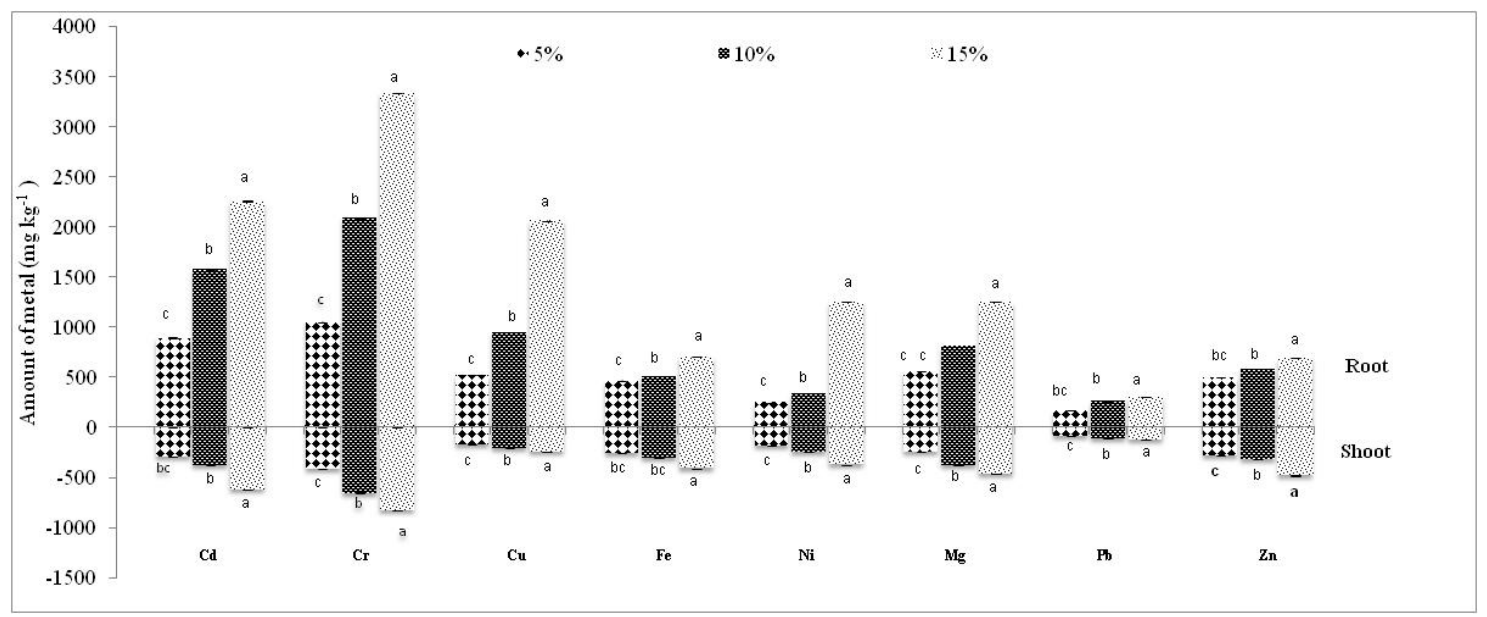

Figure 3. Concentration of various heavy metals in root and shoot of 35 days old lemongrass plants under different levels of TS; Values are the means \pm standard deviation $(n=9)$; Means with similar letters are not significantly different at $P<0.05$ according to Duncans multiple range test

\section{Antioxidant activity analysis based on the scavenging of DPPH radical}

The inhibition (\%) and absorbance of 35 days-old-plants indicates that with increasing concentration of stock solution, absorbance of light goes on increasing from 0.076 to 0.12 in stock solutions of $2-20 \mu \mathrm{g} \mathrm{ml}{ }^{-1}$ at $517 \mathrm{~nm}$ wavelengths of light for control plants. Antioxidant activity decreases with increasing concentration of stock solutions. Range of percentage inhibition was 79.3 to $56.6 \%$ in control and 83.85 to $59.9 \%$ in $2-20 \mu \mathrm{g} \mathrm{ml}^{-1}$ concentration of stock solution for $15 \%$ tannery sludge concentrations (Figs. 4 and 5).

\section{Discussion}

Heavy metal pollution has become a global environmental issue and posing serious threat for safe food production (Hu et al., 2017). In present study, the amount of heavy metals present in the TS was found in higher concentrations whereas these metals were found in the order of $\mathrm{Cr}>\mathrm{Cd}>\mathrm{Cu}>\mathrm{Zn}>\mathrm{Mg}>\mathrm{Ni}>\mathrm{Fe}>\mathrm{Pb}$. Different physicochemical properties of soil with the different concentrations of tannery sludge application denoted that $15 \% \mathrm{TS}+\mathrm{S}$ has the highest values for the all pollution parameters than other concentrations of tannery sludge amended soil. The amount of heavy metals was enhanced with increasing concentration of tannery sludge application. 
The concentration of all heavy metals increased with increasing concentrations of tannery sludge in soil in the order of $0 \%<5 \%<10 \%<15 \%$. The $\mathrm{pH}$ is increased from 8.01-8.70 (Table 1). Previously, an increase in $\mathrm{pH}$ was reported to increase the adsorption of metals by competition between protons and metal cations and by the increase in the solubility of organic matter (Werkenthin et al., 2014). The increased in the $\mathrm{pH}$ was might be due to the use of alkalis and acid in tanning process (Kesarwani et al., 2015). The increased values of soil ECe are corroborates with Carmo et al. (2016)_who reported that the ECe evaluates the concentration of soluble salts present in the soil. Higher ECe in the soil implies higher concentrations of heavy metals in the soil are present in soluble form. The highest amount of TDS was recorded in 100\% concentrations of soil was confirmed by previous studies of Sabur et al. (2013). All other physico-chemical parameters increased by increasing the percentage of sludge in the soil.

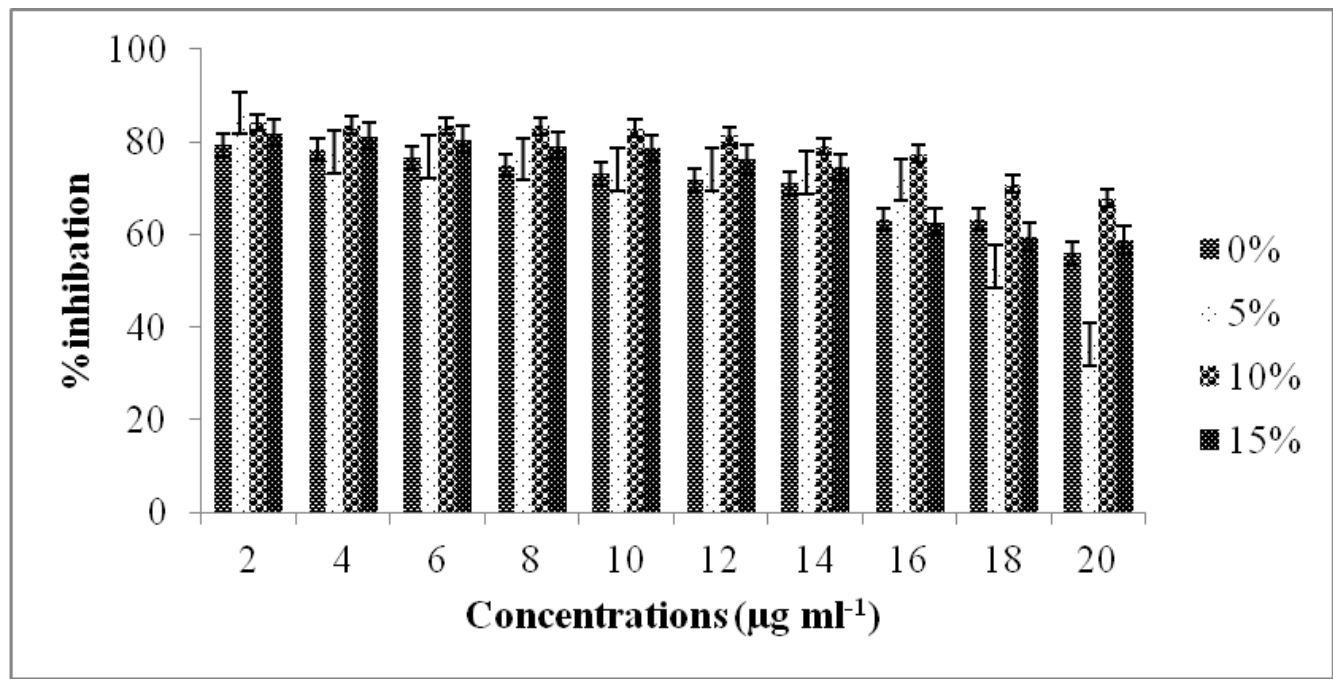

Figure 4. Variation in percentage inhibition of various concentrations of 35 days old lemongrass plants extract growing in different concentrations of tannery sludge amended soil

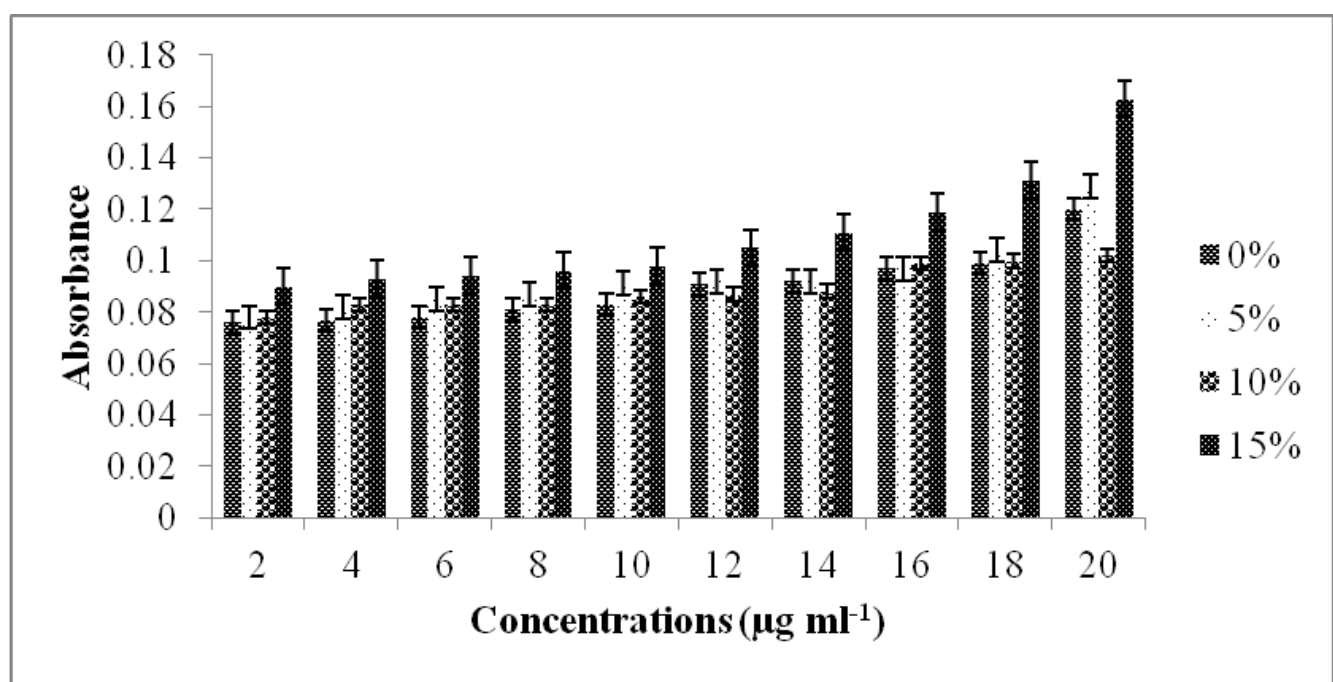

Figure 5. Variations in absorbance of various concentrations of extract of 35 days old lemongrass plants growing in different concentrations of tannery sludge amended soil i.e., 0, 5, 10 , and $15 \%$ 
The morphological traits such as the fresh weight, dry weight, number of roots, number of leaves, number of tillers, and shoot length as well as the chlorophyll contents were reduced in TS treatments as compared with control (Table 2; Fig. 2). The reductions in morphological attributes and chlorophyll contents possibly due to increased amounts of heavy metals e.g., $\mathrm{Cd}, \mathrm{Cr}, \mathrm{Pb}, \mathrm{Cu}$ and $\mathrm{Zn}$ present in sludge that might cause stress conditions to the growing lemongrass plants. Recently, Shah et al. (2017) reported that maximum growth of plants showed highly alkaline soil whereas Patel and Patra (2017) reported substantial reductions in dry weight as well as other morpho-physiological features of plants grown in metal contaminated soil. Though, a plant that was not such amendments was found with normal growth. Interestingly, the growth rate was higher during first week of experiment due to presence of some essential metals in TS amended soil. Excessive accumulation of heavy metals in plants disrupts various physiological processes such as stomatal conductance, photosynthesis, transpiration and enzymatic activities were badly affected (Farooqi et al., 2009). Significant reductions were observed in the morphological growth of maize as well as dry biomass accumulation when grown under marble effluent amended soil (Farid et al., 2020).

The amount of heavy metals was estimated in the roots and shoots of lemongrass growing in different concentration of TS after 35 days showed the following trend of metal uptake i.e., $\mathrm{Cr}>\mathrm{Cd}>\mathrm{Cu}>\mathrm{Ni}>\mathrm{Fe}>\mathrm{Zn}>\mathrm{Mg}>\mathrm{Pb}$. It was observed that metal uptake was higher in roots as compared to shoots whereas uptake of $\mathrm{Cr}$ by root and shoot was higher at $15 \%$ concentration as compared to all the other concentrations i.e., 0,5 and $10 \%$. The minimum amount of $\mathrm{Pb}$ was observed in 0 and $5 \%$ treatments in the roots and in shoots respectively (Fig. 3). Previously, Andaleeb et al. (2008) reported that the uptake rate of $\mathrm{Cr}$ was comparatively higher as compared to other metals present in the rhizosphere. Roots are the first vegetative part that accumulates its maximum metallic ions and thus highly affected by the concentration of heavy metals in the growth medium (Emamverdian et al., 2015). Amount of metals accumulated in roots were comparatively higher than shoots at all TS levels. Thamayanthi et al. (2013) also observed higher accumulation of metallic ions into the roots of Tagetes erecta followed by aerial parts respectively. Excessive accumulation of heavy metals in the different plant parts especially in the roots was due to the immobilization of metallic ions in the vacuole of plant root cells (Oliveira, 2012; Nematshahi et al., 2012). Accumulation of heavy metals ultimately reduces the dry matter production with limited development of stems and leaves during early growth of plants. Previous findings of Maksymiec (2007) confirmed that lemongrass can accumulate lower amounts of heavy metals whereas excessive amounts could be lethal for lemongrass plants. So, lemongrass could be grown successfully in low to mild concentration of metal contaminated soil in accordance to its phytoextraction capabilities.

The activities of various antioxidants i.e., SOD, POX, CAT etc. remained higher in plants grown under stress environment. Stress condition generally enhanced the antioxidant activities to neutralize the over-production of ROS (Li et al., 2017). In present study, the 2, 2-diphenyl-1-picrylhydrazyl (DPPH) radical scavenging assay was checked. An antioxidant activity was found to be increased (Figs. 4 and 5). by increasing concentrations of TS treatment that confirms the findings of Balakrishnan et al. (2014) who stated that antioxidant activity increases with increasing concentrations of sludge. Overall, lemongrass could be grown in metal contaminated soils as a phytoremediation approach. 


\section{Conclusions}

Tannery sludge (TS) application reduced the morphological growth as well as chlorophyll contents of lemongrass and such effects were more prominent at $15 \%$ TS treatment. Moreover, the metal accumulation concentrations varied with different TS treatments. The anti-oxidant activities were increased under TS treatments than control whereas the overall trend of metal uptake was recorded as: $\mathrm{Cr}>\mathrm{Cd}>\mathrm{Cu}>\mathrm{Ni}>\mathrm{Mg}>\mathrm{Fe}>\mathrm{Zn}>\mathrm{Ni}>\mathrm{Pb}$ both in root and shoot under all $\mathrm{TS}$ treatments. This study indicates that lemongrass has phytoremediation potential due to its accumulation of metals and induction of antioxidant enzyme activity and thus can be used for heavy metal extraction of Tannery sludge. Future investigations are needed to enhance the metal up take efficiency of lemongrass by using plant growth promoters to cleanse the metal contaminated soils.

Acknowledgments. Thanks are due to University of the Punjab for the financial assistance in the form of PURC research project to SAK.

Conflict of interests. It is declared that there is no conflict of interests.

\section{REFERENCES}

[1] Ali, H., Khan, E. (2017): Environmental chemistry in the twenty-first century. Environmental Chemistry Letters 15(2): 329-346.

[2] Ali, H., Khan, E., Sajad, M. A. (2013): Phytoremediation of heavy metals. Concepts and applications. - Chemosphere 91: 869-881.

[3] Anand, K. M., Goyal, R., Bhat, G. S., Kamath, S., Aggarwal, M., Bhandarkar, M. A., Sukreeth, S. (2011): Antioxidant property of a novel lemongrass oil mouth wash: an experimental study. - Recent Research in Science and Technology 3(10): 14-18.

[4] Andaleeb, S. (2008): Caring for children: a model of healthcare service quality in Bangladesh. - International Journal for Quality in Health Care 20(5): 339-345.

[5] Ashraf, U., Tang, X. (2017): Yield and quality responses, plant metabolism and metal distribution pattern in aromatic rice under lead $(\mathrm{Pb})$ toxicity. Chemosphere 176: 141-155.

[6] Ashraf, U., Kanu, A. S., Mo, Z., Hussain, S., Anjum, S. A., Khan, I., Abbas, R. N., Tang, X. (2015): Lead toxicity in rice: effects, mechanisms, and mitigation strategies-a mini review. - Environmental Science and Pollution Research 22(23): 18318-32.

[7] Ashraf, U., Hussain, S., Anjum, S. A., Abbas, F., Tanveer, M., Noor, M. A., Tang, X. (2017): Alterations in growth, oxidative damage, and metal uptake of five aromatic rice cultivars under lead toxicity. - Plant Physiology and Biochemistry 115: 461-471.

[8] Ashraf, U., Hussain, S., Akbar, N., Anjum, S. A., Hassan, W., Tang, X. (2018): Water management regimes alter $\mathrm{Pb}$ uptake and translocation in fragrant rice. Ecotoxicology and Environmental Safety 149: 128-134.

[9] Azizullah, A., Khattak, M. N. K., Richter, P., Hader, D. P. (2011): Water pollution in Pakistan and its impact on public health. A Review. - Environment International 37: 479-497. 
[10] Balakrishnan, B., Paramasivam, S., Arulkumar, A. (2014): Evaluation of the lemongrass plant (Cymbopogon citratus) extracted in different solvents for antioxidant and antibacterial activity against human pathogens. - Asian Pacific Journal of Tropical Medicine 4: 134-139.

[11] Ball, D. F. (1964): Loss on ignition as an estimate of organic matter and organic carbon in non-calcareous soils. - European Journal of Soil Sciences 15: 84-92.

[12] Bareen, F., Tahira, E. S. A. (2011): Metal accumulation potential of wild plants in tannery effluent contaminated soil of Kasur, Pakistan: field trials for toxic metal cleanup using Suaeda fruticosa. - Journal of Hazardous Material 186(1): 443-450.

[13] Beesley, L., Moreno-Jimenez, E., Gomez-Eyles, J. L. (2011): Effects of biochar and green waste compost amendments on mobility, bioavailability and toxicity of inorganic and organic contaminants in a multi-element polluted soil. Environmental Pollution 158: 2282-2287.

[14] Brand-Williams, W., Cuvelier, M. E., Berset, C. (1995): Use of free radical method to evaluate antioxidant activity. - Lebensmittel-Wissenschaft und Technologie 28: 25-30.

[15] Carmo, D. L., Lima, L. B., Silva, C. A. (2016): Soil Fertility and Electrical Conductivity Affected by Organic Waste Rates and Nutrient Inputs. - Revista Brasilieria de Ciencia do Solo 40: 150-152.

[16] Clarke, G., Ting, K. N., Wiart, C., Fry, J. (2013): High correlation of 2, 2diphenyl-1-picrylhydrazyl (DPPH) radical scavenging, ferric reducing activity potential and total Phenolics content indicates redundancy in use of all three assays to screen for antioxidant activity of extracts of plants from the Malaysian rainforest. - Antioxidants 2: 1-10.

[17] Edwards, C. A. (ed.) (2013): Environmental Pollution by Pesticides. - Springer Science \& Business Media, New York.

[18] Emamverdian, A., Ding, Y., Mokhberdoran, F., Xie, Y. (2015): Heavy metal stress and some mechanisms of plant defense response. - Scientific World Journal 1: $1-18$.

[19] Farid, M., Farid, S., Zubaur, M., Rizwan, M., Ishaq, H. K., Ali, S., Ashraf, U., Alhaithloul, H. A. S., Gowayed, S., Soliman, M. H. (2020): Efficacy of Zea mays L. for the management of marble effluent contaminated soil under citric acid amendment; morpho-physiological and biochemical response. - Chemosphere 240: 124-130.

[20] Farooqi, Z. R., Iqbal, M. Z., Kabir, M., Shafiq, M. (2009): Toxic effects of lead and cadmium on germination and seedling growth of Albizia lebbeck (L.) Benth. Pakistan Journal of Botany 41(1): 27-33.

[21] Figueirinha, A., Cruz, M. T., Fransisco, V., Lopes, M. C., Batista, M. T. (2010): Anti-inflammatory activity of Cymbopogon citratus leaf infusion in lipopolysaccharide-stimulated dendritic cells: contribution of the polyphenols. Journal of Medicinal Food 13(3): 681-690.

[22] Greenberg, A. E., Clesseri, L. S., Eaton, A. D. (1998): Standard Methods for the Examination of Water and Waste Water. 20 ${ }^{\text {th }}$ Ed. - American Public Health Association, Washington pp. 215-252.

[23] Hashem, M. A., Nur-A-Tomal, M. S., Mondal, N. R., Rahman, M. A. (2017): Hair burning and liming in tanneries is a source of pollution by arsenic, lead, zinc, manganese and iron. - Environmental Chemistry Letters 15(3): 501-506. 
[24] Henschel, S., Atkinson, R., Zeka, A., Le-Tertre, A., Analitis, A., Katsouyanni, K., Chanel, O., Pascal, M., Forsberg, B., Medina, S., Goodman, P. G. (2012): Air pollution interventions and their impact on public health. - International Journal of Public Health 57: 757-768.

[25] Hu, B. F., Chen, S. C., Hu, J., Xia, F., Xu, J. F., Li, Y., Shi, Z. (2017): Application of portable XRF and VNIR sensors for rapid assessment of soil heavy metal pollution. - Plos One. DOI: 10.1371/journal.pone.0172438.

[26] Jasha, M. A. H. (2014): Trace and Essential Elements Analysis in Cymbopogon citratus (DC.) Stapf Samples by Graphite Furnace-Atomic Absorption Spectroscopy and Its Health Concern. - Journal of Toxicology. http://dx.doi.org/10.1155/2014/690758.

[27] Kesawani, K., Vats, A. (2015): Awareness regarding the impact of waste disposal of packaging and carrying material on health: a study in Gadarpur block of Uttarakhand. - International Journal of Applied Agricultural Research 13(2): 232236.

[28] Kumar, A., Malik, F., Bhushan, S., Sethi, V. K., Shahi, A. K., Taneja, S. C., Singh, J. (2008): An essential oil and its major constituent iso intermedeol induce apoptosis by increased expression of mitochondrial cytochrome $\mathrm{c}$ and apical death receptors in human leukemia HL-60 cells. - Chemico-Biological Interactions 171(3): 332-347.

[29] Li, C. C., Yu, H. F., Chang, C. H., Liu, Y. T., Yao, H. T. (2017): Effects of lemongrass oil and citral on hepatic drug-metabolizing enzymes, oxidative stress, and acetaminophen toxicity in rats. - Journal of Food and Drug Analysis 26(1): 432-438.

[30] Lou, X. S., Xue, Y., Wang, Y. L., Cang, L., Xu, B., Ding, J. (2015): Source identification and apportionment of heavy metals in urban soil profiles. Chemosphere 127: 152-157.

[31] Maksymiec, W. (2007): Signaling responses in plants to heavy metal stress. Acta Physiologia Plantarum 29(3): 177-187.

[32] Morkunas, I., Agnieszka, W., Van, C. M., Renata, R. S., Philippe, J. (2018): The Role of Heavy Metals in Plant Response to Biotic Stress. - Molecules 23(9): 2320 .

[33] Nematshahi, N., Lahouti, M., Ganjeali, A. (2012): Accumulation of chromium and its effect on growth of Allium cepa cv. Hybrid. - European Journal of Experimental Biology 2(4): 969-974.

[34] Ogura, R., Ikeda, N., Yukietal, K. (2008): Geno toxicity studies on green tea catechin. - Food and Chemical Toxicology 46(6): 2190-2200.

[35] Oliveira, H. (2012): Chromium as an environmental pollutant: insights on induced plant toxicity. - Journal of Botany. DOI: 10.1155/2012/375843.

[36] Patel, A., Patra, D. D. A. (2017): Sustainable Approach to Clean Contaminated Land Using Terrestrial Grasses. - In: Bauddh, K. et al. (eds.) Phytoremediation Potential of Bioenergy Plants. Springer, Singapore, pp. 305-331.

[37] Peng, J. F., Song, Y. H., Yuan, P., Cui, X. Y., Qiu, G. L. (2009): The remediation of heavy metals contaminated sediment. - Journal of Hazardous Material 161(2): 633-640.

[38] Rajeshwara Rao, B. R., Adinarayana, G., Rajput, D. K., Kumar, A. N., Syamasundar, K. V. (2015): Essential oil profiles of different parts of East Indian 
lemongrass \{Cymbopogon flexuosus (Nees ex Steud.) Wats.\}. - Journal of Essential Oil Research 27(3): 225-231.

[39] Sabur, M. A., Khan, A., Safiullah, S. (2013): Treatment of tannery effluent by locally available commercial grade lime. - Journal of Scientific Research 5(1): 143-150.

[40] Saeed, G. K. (1980): Technical Guide for Chemical Analysis of Soil and Water. Technical Guide for Chemical Analysis of Soil Water Samples. - Soil Survey of Pakistan, Lahore, pp. 35-40.

[41] Shah, K., Mankad, A. U., Reddy, M. N. (2017): Cadmium accumulation and its effects on growth and biochemical parameters in Tagetes erecta L. - Journal of Pharmacognosy and Phytochemistry 6(3): 111-115.

[42] Teng, Y. G., Wu, J., Lu, S. J., Wang, Y. Y., Jiao, X. D., Song, L. T. (2014): Soil and soil environmental quality monitoring in China: a Review. - Environment International 69: 177-199.

[43] Thamayanthi, D., Sharavanan, P. S., Jayaprasad, B. (2013): Phytoremediating Capability Biochemical Changes and Nutrient Status of Marigold (Tagetes erecta L.), Plant under Cadmium Stress. - International Journal of Research in Plant Sciences 3: 57-63.

[44] Thanikaivelan, P., Rao, J. R., Nair, B. U., Ramasmi, T. (2005): Recent trends in leather making: processes, problems, and pathways. - Critical Reviews in Environmental Science and Technology 35(1): 37-79.

[45] Verma, S. K., Singh, K., Gupta, A. K., Pandey, V. C., Trivedi, P., Verma, R. J., Patra, D. D. (2014): Aromatic grasses for phytomanagement of coal fly ash hazards. - Ecological Engineering 73: 425-428.

[46] Werkenthin, M., Kuge, B., Wessolek, G. (2014): Metals in European roadside soil and soil solution. A Review. - Environmental Pollution 189: 98-110. 